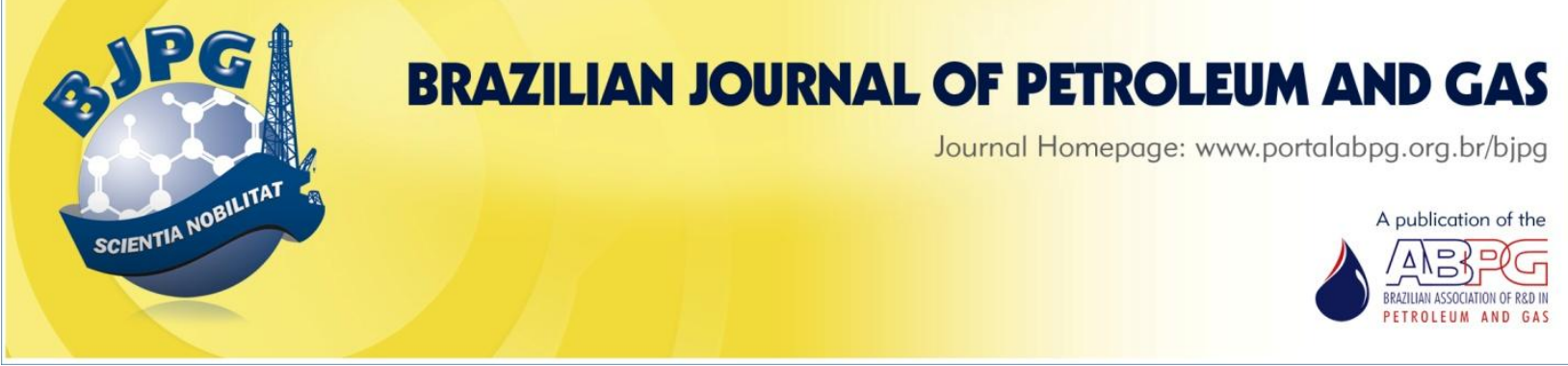

\title{
BIOREMEDIATION OF FLUVIAL SEDIMENT CONTAMINATED BY ANGOLAN CRUDE OIL
}

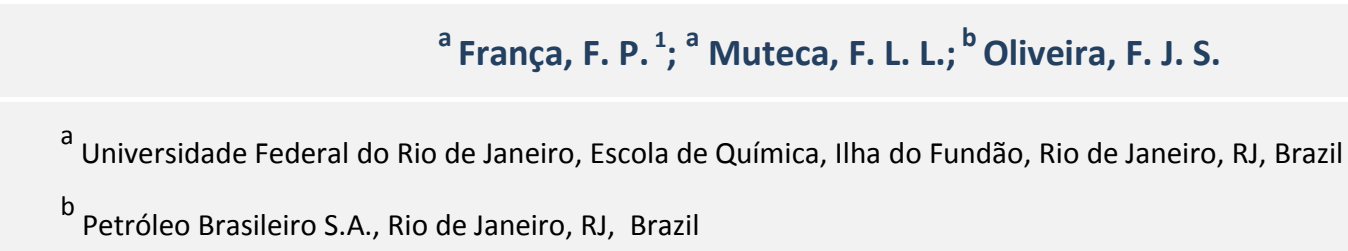

\section{ABSTRACT}

A monitoring program was set up to verify the efficiency of techniques used in the bioremediation of sediments contaminated by crude oil from Angola, originated from the banks of the Nzombo river (Zaire, Angola). The contaminated sediment samples had initial total petroleum hydrocarbon (TPH) concentrations of $21.5 \mathrm{~g} / \mathrm{kg}$. The samples were treated alone and in mixtures with non-contaminated fluvial sediments, in proportions of 9,17 , and $27 \%$ ( $\mathrm{m} / \mathrm{mby}$ mass) of the former, seeking to simulate landfarming conditions. The bioremediation of the contaminated sediment led to the removal of $62 \%$ of the TPHs and $16 \%$ of the polycyclic aromatic hydrocarbons (PAHs) monitored. The tests with the mixtures containing 9, 17, and $27 \%$ of contaminated sediment yielded TPH removals of 80,85 , and $62.5 \%$, respectively, and the complete removal of the 16 PAHs monitored. Thus, bioremediation represents an efficient and low cost alternative for the treatment of the fluvial sediment studied.

\section{KEYWORDS}

crude oil; fluvial sediment; bioremediation; petroleum hydrocarbons; polycyclic aromatic hydrocarbons

\footnotetext{
${ }^{1}$ To whom all correspondence should be addressed.

Address: Universidade Federal do Rio de Janeiro, Escola de Química, Av. Athos da Silveira Ramos, 149, Bloco E, Ilha do Fundão, Rio de Janeiro, Brazil

Zip Code: 21941-909|e-mail: fpfranca@eq.ufri.br

doi:10.5419/bjpg2014-0013
} 


\section{INTRODUCTION}

Petroleum is one of the main sources of energy used on the planet. Its strong positive impact on the macro economy has encouraged the development of an oil and natural gas sector in many countries. Currently, the oil and gas sector is one of the main contributors to the gross domestic product (GDP) of Angola which, during the past decade, has become one of the major producers of crude oil on the African continent (EIA, 2011).

Since 2009, several oil leaks have been reported in the Angolan provinces of Cabinda and Zaire, locations that have an intense activity of oil and gas exploration and production. The crude oil leaks in these areas have led to a range of adverse economic and environmental consequences. Figueiredo (2009) has reported that, after the rupturing of a crude oil pipeline, the Nzombo river was severely polluted (at Kifuma, municipality of Soyo, province of Zaire), rendering the water unfit for consumption by the local population and those of neighboring areas as well as affecting a large area of farmland. In November 2011, oil sleeks from an "unknown origin" contaminated a vast stretch of the coastline in the municipality of Soyo, adversely affecting the biodiversity of the region and the subsistence activities of the local population (Figueiredo, 2011).

Among the most notorious environmental contaminants present in petroleum are the aromatic hydrocarbons and polycyclic aromatic hydrocarbons, which are considered to be recalcitrant due to their strong molecular bonds. These contaminants persist in the environment for long periods of time posing a threat to human health and the environment. Many of these compounds are toxic, mutagenic or carcinogenic, and they can also accumulate in the food chain (Castro et al., 2004).

In light of these environmental and economic issues, the present research aimed to develop mechanisms to reduce environmental liabilities in Angola. It sought to verify the potential of bioremediation as a low cost technique for the recovery of fluvial sediments contaminated by petroleum hydrocarbons.

\section{MATERIALS AND METHODS}

The samples of fluvial sediments with and without crude oil contamination were collected from the banks of the Nzombo River, in the municipality of Soyo, in the Angolan province of Zaire. The samples used for the chemical and microbiological tests were placed in sterilized glass flasks and stored at $4^{\circ} \mathrm{C}$ prior to the laboratory tests. The samples of approximately $50 \mathrm{~kg}$ of sediment (with and without crude oil contamination) were collected and placed in plastic bags, which were sealed and stored at $4^{\circ} \mathrm{C}$ until granulometric and bioremediation tests were carried out.

\subsection{Bioremediation experiments}

The bioremediation experiments were carried out over 90 days in high density polyethylene reactors $(0.22 \mathrm{~m}$ width $\times 0.22 \mathrm{~m}$ length $\times 0.09 \mathrm{~m}$ depth). Each reactor had $2 \mathrm{~kg}$ of sediment to be treated (Figure 1). All of the reactors were supplemented with commercial fertilizer (NPK 10:10:10; Ouro Verde, Brazil) in order to obtain an initial $C: N: P$ ratio of 100:10:10. The tests were carried out at ambient temperature (between 25 and $35^{\circ} \mathrm{C}$ ) and the sediment was maintained at 70 $80 \%$ of its water retention capacity using sterile distilled water. The supply of oxygen was maintained by turning every $72 \mathrm{~h}$, using sterile glass rods. The water retention capacity of the sediment was determined according to the procedures described by Waterwood et al. (1991).

Tests were conducted with the crude oil contaminated sediment alone, from now on referred to as contaminated sediment in natura, and in mixtures with non-contaminated sediments, in proportions of 9,17 , and $27 \%$ (by mass) of

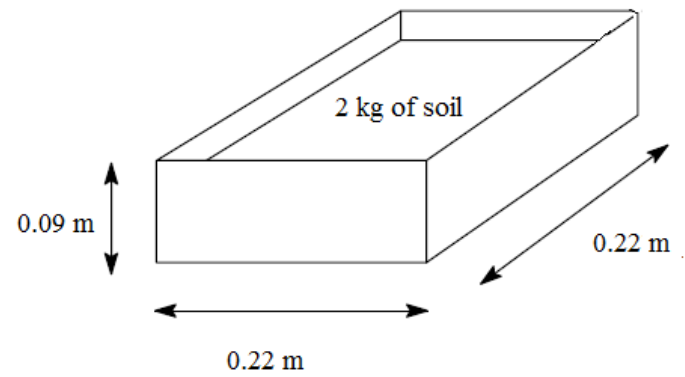

Figure 1. Bioreactor used in bioremediation experiments. 
contaminated sediments, seeking to simulate landfarming conditions. The mixing of these sediments was carried out in the reactors, with sterile stainless steel spatulas and glass rods. The results of the total petroleum hydrocarbons were subjected to an analysis of variance (ANOVA) and to the multiple comparison Tukey test ( 0.05 level of significance). In all cases, statistic analyses were performed with the aid of the Statistica, version 5.5 (StatSoft Inc) computer program.

The abiotic losses in the experiments were determined in parallel experiments, carried out under the same experimental conditions and with the addition of a $10 \%$ (by mass) solution of mercury nitrate (Vetec, Rio de Janeiro, Brazil). Control reactors containing in natura sediments, contaminated with Angolan crude oil, were also subjected to the biotreatment.

The bioreactors were submitted to a sampling process that consisted of collecting $10 \mathrm{~g}$ of the sediment at three equidistant points within the reactor. The samples were mixed and homogenized to give a single final sample. The results of the biodegradation considered abiotic losses.

\subsection{Analytical determinations}

The quantification of the total heterotrophic bacteria (THB) and total fungi (TF) was carried out by the pour plate technique using Agar Nutriente (Merck, Darmstadt, Germany) and 2\% Agar Sabouraud (Merck, Darmstadt, Germany), respectively. The plates were incubated at $30^{\circ} \mathrm{C}$ for $48 \mathrm{~h}$ for the quantification of the bacteria, and for $72 \mathrm{~h}$ to determine the fungi.

Soil-water content was determined using porcelain crucibles and an infrared humidity analyzer. Soil $\mathrm{pH}$ values were measured in 1:1 $(w / w)$ distilled water suspensions. Soil size distribution analysis was performed using conventional screen procedures for the separation of stones and sand. Screening was followed by sedimentation of fine materials in a sodium orthophosphate solution. Total nitrogen and total phosphorus concentrations were determined by spectrophotometry using the methods USEPA 351.2 and 365.3, respectively (EPA, 1996).

The organic extracts for the determination of the hydrocarbon concentration of the sediment were obtained according to the method USEPA
3550, using ultrasound and analytical grade dry dichloromethane (EPA, 1996). The solvent was purged in a TurboVap II concentrator with nitrogen flow at $40^{\circ} \mathrm{C}$. The organic extracts were cleaned up by silica gel column chromatography according to the method USEPA $3630 \mathrm{C}$, prior to the chromatographic determinations (EPA, 1996).

The TPHs in the organic extracts of the sediment were quantified by gas chromatography with a flame ionization detector, according to the method USEPA 8015C (EPA, 1996), using a Shimadzu Europe gas chromatograph (model QP5050A) equipped with a Valcobond VB-5 column $(30 \mathrm{~m}$ length $\times 0.25 \mathrm{~mm}$ diameter $\times 0.25 \mu \mathrm{m}$ thickness). Integration was carried out so that the TPH values covered the TPH results in the ranges for gasoline, kerosene, diesel and fuel oil, as well as the unresolved complex mixture (UCM) fraction on the chromatogram. Prior to the determinations, $\mathrm{C}_{20}-\mathrm{d}_{42}$ and $\mathrm{C}_{24}-\mathrm{d}_{50}$ were added to the samples as internal standards.

The concentrations of naphthalene, acenaphthylene, acenaphthene, anthracene, fluorene, phenanthrene, fluoranthene, benzo[a]antraceno, benzo[k]fluoranthene, pyrene, chrysene, benzo[a]pyrene, indeno[1,2,3-cd]pyrene, dibenzo[a,h]anthracene, and benzo[ghi]perylene in the organic extracts were determined by gas chromatography coupled to mass spectrometry, according to the method USEPA 8270 C (EPA, 1996). A Thermo Finnigan chromatograph (model Focus GC) was used, equipped with an RTX-5MS column $(30 \mathrm{~m}$ length $\times 0.25 \mathrm{~mm}$ diameter $\times 0.25 \mu \mathrm{m}$ thickness) and coupled to a Thermo Finnigan mass spectrometer (model Focus DSQ). Deuterated PAH (naphthalene- $d_{8}$, acenaphthene- $d_{10}$, phenanthrene$d_{10}$, chrysene- $d_{12}$, and perylene- $d_{12}$ ) were used as internal standard; and 2-fluorobiphenyl and terphenyl-d14 as surrogates.

All of the results are expressed as the average of three experiments.

\section{RESULTS AND DISCUSSION}

The physico-chemical characteristics of the sediments are determinant factors in the biodegradation of hydrocarbons, since they directly affect the metabolic activity of the microorganisms and are strongly related to the availability of the 
contaminants. In environments where biodegradation is the main process involved in the mass reduction of a contaminant, sediment granulometry is considered to be one of the most important parameters in the bioprocess. The granulometric distributions of the contaminated sediment in nature and of the uncontaminated sediment were similar, with a predominance of fine sand, medium sand, and coarse sand $(49 \pm 3 \%, 30 \pm$ $1 \%$, and $14 \pm 2 \%$, respectively). Silt and clay contents were low (approximately 3 and $2 \%$, respectively), regardless of the presence of oil contamination. These results are consistent with alluvial characteristics, considering that the sample came from a location along the banks of a river. Based on the results, one can assume that the high content of sandy materials would favor mass transfer between the solid, liquid, and gaseous phases of the sediment, as well as the processes associated with the transport of matter between the atmosphere and the solid substrate. These factors can lead to an increase in: 1 - nutrient availability; 2 - electron acceptors, especially oxygen; and 3 - the mixing of microorganisms and hydrocarbons, favoring the biodegradation (Marin et al., 2005).

The $\mathrm{N}$ and $\mathrm{P}$ concentrations were $66 \pm 5$ and 104 $\pm 9 \mathrm{mg} / \mathrm{kg}$, respectively. Nitrogen is required for the formation of amino acids and peptides, and phosphorous is an important constituent of DNA, RNA, phospholipids, and some vitamins. Moreover,
$\mathrm{C}: \mathrm{N}$ and $\mathrm{C}: \mathrm{P}$ ratios are significant for determining the availability of essential nutrients for the metabolic activity of micro-organisms. So, having low $\mathrm{N}$ and $\mathrm{P}$ contents can be considered a limiting factor, particularly when the contaminant acts as a source of carbon (Röling \& Van Verseveld, 2002), which is the reason for the adjustment of the $\mathrm{C}: \mathrm{N}: \mathrm{P}$ ratio to $100: 10: 10$ at the beginning of the tests.

The uncontaminated sediment samples had TPH contents below the limit of quantification (LOQ), which was $40 \mathrm{mg} / \mathrm{kg}$. Also, in these samples, the concentrations of naphthalene, acenaphthylene, acenaphthene, chrysene, fluorene, phenanthrene, anthracene, benzo[a]antraceno, fluoranthene, pyrene, benzo[a]pyrene, benzo[k]fluoranthene, indeno[1,2,3-cd]pyrene, dibenzo[a,h]anthracene, and benzo[ghi]perylene were below the LOQ $(0.5$ $\mathrm{mg}$ of $\mathrm{PAH} / \mathrm{kg}$ ).

The TPH content of the contaminated sediment sample collected in Angola was approximately 21.5 $\mathrm{g} / \mathrm{kg}$, the UCM being quantified on the chromatogram as approximately $14 \mathrm{~g} / \mathrm{kg}$ (Figure 2), indicating the presence of degraded hydrocarbons, associated with weathered oils or possible chronic oil inputs. The relation between the resolved aliphatic hydrocarbons and the UCM is used as a criterion for the diagnosis of petroleum degradation in the environment. Low values suggest the degradation process has occurred while high values indicate the recent introduction

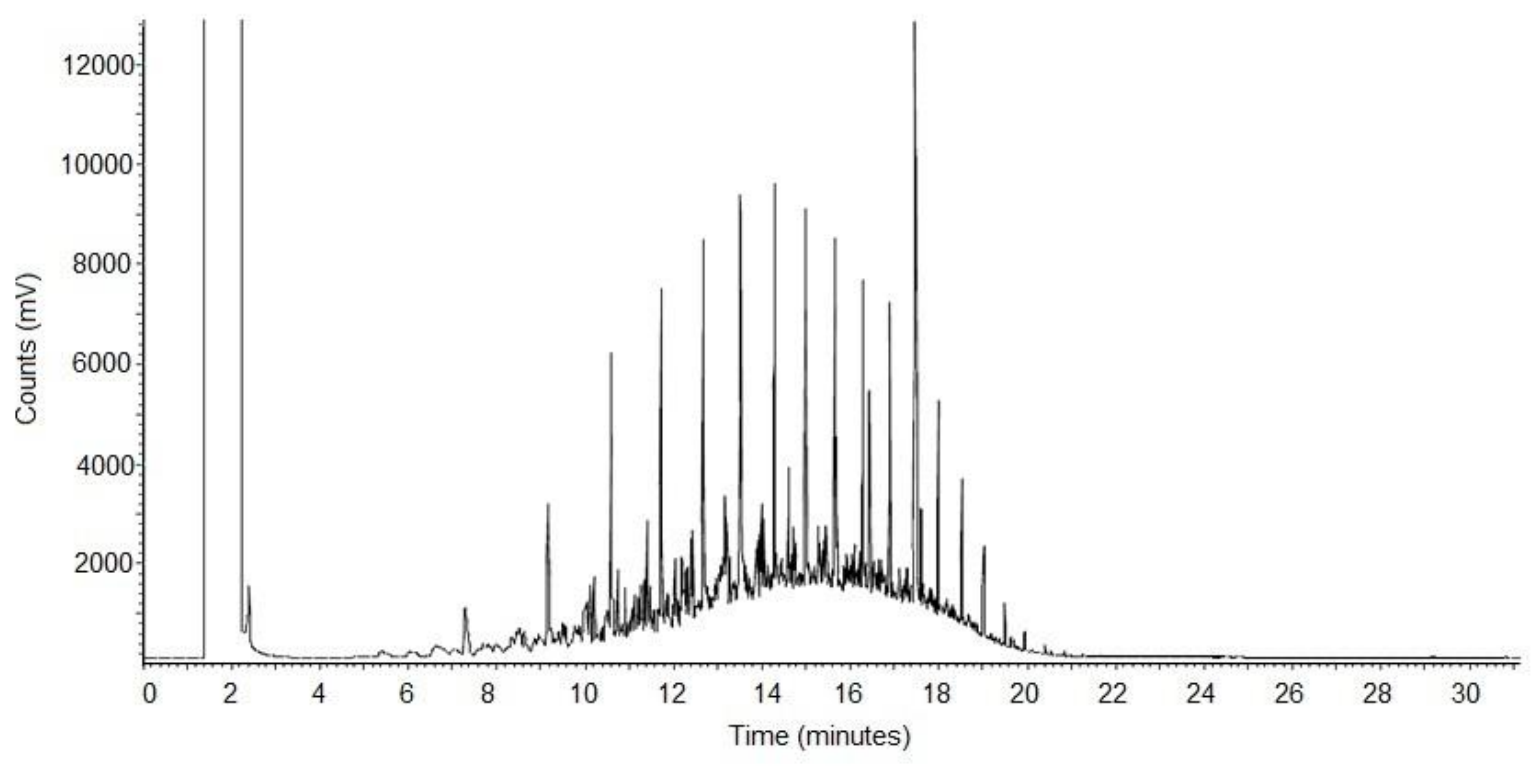

Figure 2. Chromatogram obtained from organic extract of a Angolan sediment contaminated with petroleum. 
of oil. The results of 0.53 obtained in the analysis of the relation between resolved aliphatics and the UCM mean that the hypothesis of chronic inputs can be discarded and indicates recent contamination.

The ratios between pristane and $\mathrm{C}_{17}$ and between phytane and $\mathrm{C}_{18}$ are other correlations used to determine whether or not the petroleum hydrocarbons present in the environment are recent. They can be used to characterize the degree of degradation and weathering of the petroleum in the environment, since the linear alkane chains are more easily biodegraded by microorganisms than branched hydrocarbons. Low values $(<2)$ suggest the presence of weathered oil (Colombo et al., 1989) and corroborate previous results. Trindade et al. (2005) defined weathering as the result of biological, chemical and physical processes which can affect the type of hydrocarbons which remain in the sediment. These processes increase the absorption of hydrophobic organic contaminants by the sediment matrix, reducing the rate and degree of biodegradation and leaving, over time, the compounds for which biodegradation is less favorable. From an analysis of the chromatogram in Figure 2 one can verify that there is an absence of doublet peaks and the predominance of TPHs in the range of diesel, that is, TPH-DRO, indicating contamination by light or medium crude oil.

The PAHs present in highest concentrations in the contaminated sediment in natura were phenanthrene $(70.1 \pm 5.0 \mathrm{mg} / \mathrm{kg})$ and anthracene $(102.7 \pm 10.5 \mathrm{mg} / \mathrm{kg})$. The other PAHs monitored had similar concentrations (10.3 - $13.1 \mathrm{mg} / \mathrm{kg})$. Phenanthrene is a PAH with three condensed aromatic rings and a high octanol-water partition coefficient ( $\log K_{\text {ow }}=4.57$ ). It can therefore be considered as a low molecular weight PAH (Mao, et al., 2012; Vasconcelos et al., 2011). The toxicity of PAHs has been widely reported in the literature (Llado et al., 2014; Vasconcelos et al., 2011) and phenanthrene is considered to be a mutagenic compound that presents genotoxicity only to certain individuals. Its lipophilic nature enables this compound to be absorbed by the skin, besides being absorbed through ingestion or inhalation, being rapidly distributed throughout the organism. The anthracene has three aromatic rings ( $\log K_{\text {ow }}=$ 4.54), and studies have not been able to verify its toxicity with regard to mutagenic or carcinogenic characteristics (Pereira Netto et al., 2000). Considering the whole set of results reported to date, the bioremediation of the sediment under study is a complex process and involves compounds that can be harmful to human health, leading to the different approaches proposed for biotreatment.

\subsection{Bioremediation of contaminated sediment in natura}

During the tests, a variation in the ambient temperature of between 25 and $35^{\circ} \mathrm{C}$ was observed, which is within the range considered to be optimum for the biodegradation of hydrocarbons. The sediment's humidity remained between 70 and $80 \%$ of the water retention capacity. The presence of a suitable water content is one of the most important factors in sediment bioremediation, since the water transports nutrients and microorganisms and also enables the dispersion of cellular excretions through the medium, thus, favoring the microbial growth (Alexander, 1999).

Figure 3 shows the chromatogram for the organic extract of the sediment at the end of this experiment, indicating a notable increase in the baseline of the chromatogram. In addition, in comparison with Figure 2, a reduction can be observed in the quantity of defined peaks related to the aliphatic hydrocarbons of the crude oil. After 90 days of the bioremediation process, the TPH removal was approximately $62 \%$, which can be considered moderate, due to the high concentration of contaminants and toxicity. TPH removal result corroborates those presented by Suja et al. (2014), who performed microcosm tests with weathered oil contaminated soil, however, supplementing with mineral medium and inoculating with a previously selected mixed microbial culture. The removal of $n$-alkanes between $C_{10}$ and $C_{36}$ was high (around 90\%), corroborating reports that listed linear compounds as more easily metabolized by microorganisms than branched and aromatic compounds (Alexander, 1990). It should be noted that the period on the chromatogram where most of the peaks eluted indicated that the hydrocarbons remained in the range of lubricating oils (TPHORO). Thus, a comparison with Fig. 1 reveals that compounds with a high molecular mass remained and there was preferential degradation of aliphatic 


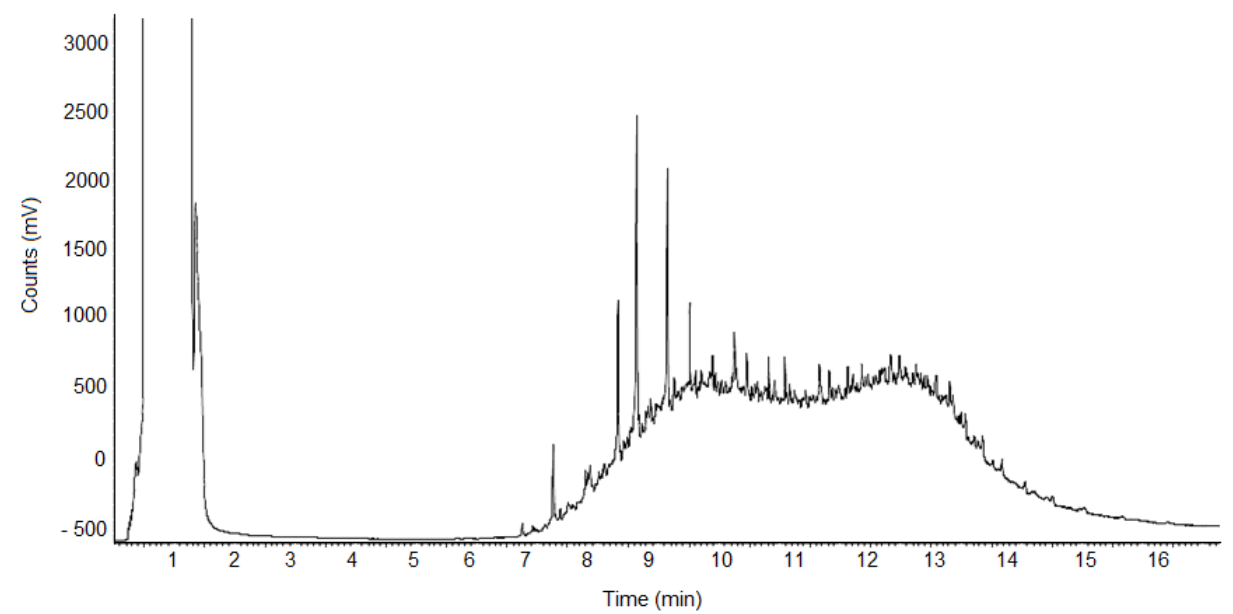

Figure 3. Chromatogram obtained for the sediment extract at the end of the first bioremediation experiments.

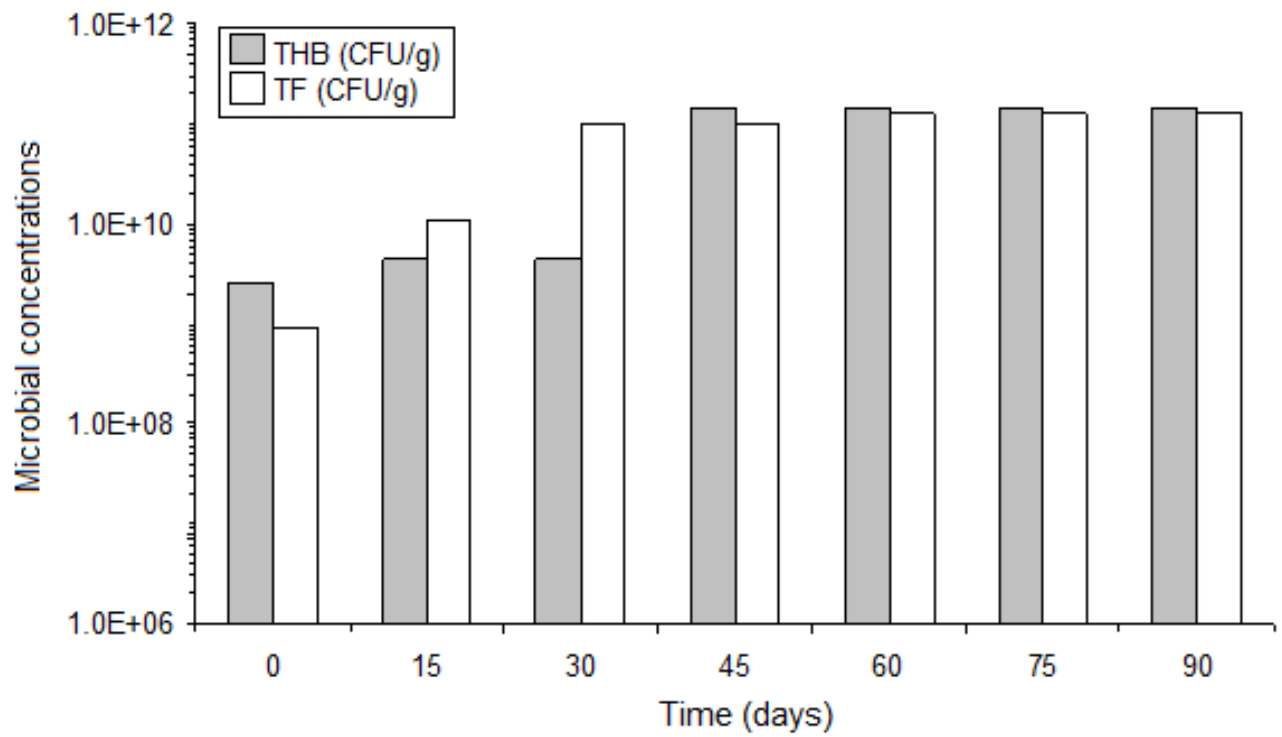

Figure 4. Concentration of total heterotrophic bacteria (THB) and total fungi (TF) in the bioremediation of the contaminated sediment in natura.

hydrocarbons of medium molecular mass. The TPH abiotic losses were quantified $(10 \pm 2 \%)$ and were related to volatilization or photochemical degradation.

At this stage of the process $2 / 3$ of the THPs were related to the resolved hydrocarbons and the UCM represented $1 / 3$ of the sediment TPHs. These results, together with the absence of pristane and phytane, reinforce the hypothesis of the occurrence of biodegradation. The removal of the PAHs monitored was approximately $16 \%$. Thus, the comparison of this result with that of the TPH biodegradation, allows one to infer that there was a preferential removal of aliphatic hydrocarbons in relation to the polyaromatic hydrocarbons, as described by the literature (Oliveira \& de França, 2005; Das \& Chandran, 2011; Vasconcelos et al., 2011; Salam, Obayori, 2014). The persistence of PAHs in the sediment should be the subject of future studies on biotreatment simulating the landfarming technique.

Figure 4 shows that the bacterial concentration increased up to a period of 45 days, when the highest concentration was identified, remaining at around $10^{11}$ cells/g until 90 days of the process. 
As observed for the bacteria, the fungal concentration also increased after the beginning of the test. However, it reached a maximum value after 30 days of biotreatment, remaining at around $10^{12} \mathrm{CFU} / \mathrm{g}$ until 90 days of the process. It is well known that both the population and the diversity of the microbiota provide important information for the evaluation of the potential for sediment's bioremediation. Thus, the results obtained to date appear to indicate the potential of the bioprocess for the remediation of the sediment under study, highlighting the importance of seeking other alternative processes in order to improve the bioremediation efficiency.

\subsection{Tests on the bioremediation of mixtures of contaminated and uncontaminated sediments}

These tests simulate the technique of landfarming, where sediments containing high concentrations of hydrocarbons are incorporated into a reactive layer of sediment that has a low concentration of hydrocarbons. The initial TPH concentrations were 1.9, 3.7, and $5.8 \mathrm{mg} / \mathrm{kg}$ in the reactors operated with the mixtures containing, respectively, 9, 17 , and $27 \%$ of contaminated sediment. Figure 4 shows the evolution of the $\mathrm{pH}$ and the TPH removal over 90 days of the process. It was assumed that, at the beginning of the test (time 0), the removal was negligible.

There was a slight reduction in the sediment $\mathrm{pH}$; however, it remained within the range of slightly acid to neutral, which is considered to be the optimum for this type of bioprocess (Franco et al., 2004). The microbial oxidation of the light and heavy oil fractions produces several types of organic acids, mainly those derived from light hydrocarbons, which can reduce the sediment's $\mathrm{pH}$. The neutral nature of the $\mathrm{pH}$ may be related to the buffering capacity of the sediment, due to the presence of salts and oxides.

Figure 5 shows that during the monitoring period the biodegradation of the hydrocarbons varied between 62 and $85 \%$. The maximum values were obtained in the tests carried out with

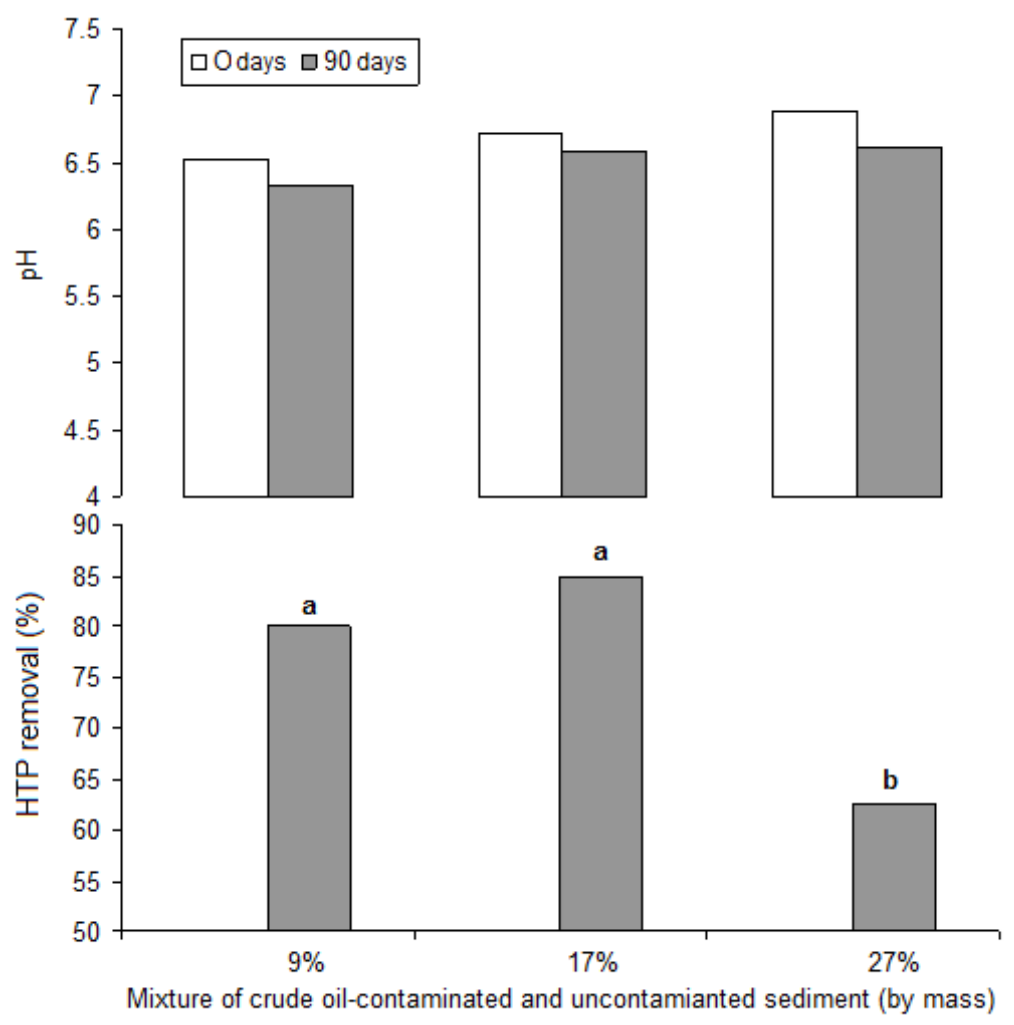

Figure 5. Results for $\mathrm{pH}$ and total petroleum hydrocarbons (TPH) biodegradation at 0 and 90 days. TPH removal at 0 days was considered to be $0 \%$. Initial TPH values of $1.9,3.7$, and 5.8 correspond to mixtures containing 9,17 , and $27 \%$ of contaminated sediment, respectively. Different lowercase letters (above the HTP removal column) indicate significant different averages ( $>5 \%$ ) according to the Tukey test. 


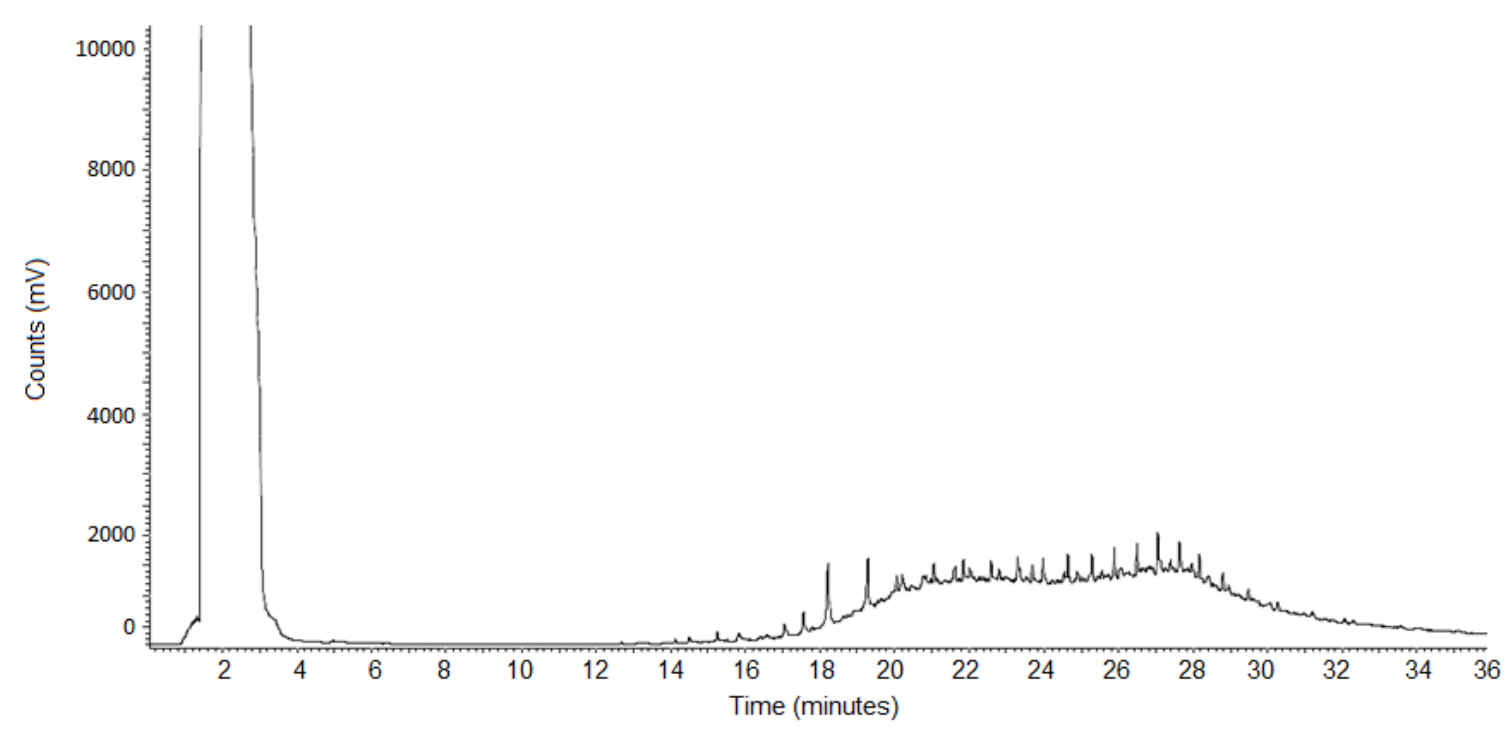

Figure 6. Chromatogram obtained for the sediment extract at the end of the tests with mixtures of contaminated $(17 \%)$ and uncontaminated sediment.

mixtures containing 9 and $17 \%$ (by mass) of the contaminated sediment. However, it should be noted that the initial TPH concentrations in the reactors increased with an increase in the contaminated sediment mass added to the uncontaminated sediment. Thus, the reduction in the TPHs, expressed as mass per kg of sediment, was greater for the tests conducted with $27 \%$ of contaminated sediment. The ANOVA, performed with the data of THP biodegradation, yielded a value of minimum significant difference of $8.3 \%$ for HTP, with a standard deviation of $3.1 \%$. Tukey test results confirmed that only the TPH removal results of the tests conducted with $27 \%$ of contaminated sediment were statistically different (at a significance level of $5 \%$ ). Thus, it was confirmed that the initial concentration of the pollutant influenced biodegradation of hydrocarbons. It was also verified that the mass of TPHs removed was proportional to the initial TPH concentration for the range of concentrations studied. Considering a linear biodegradation model, the TPH removal rates were $0.013,0.035$, and $0.040 \mathrm{mg} /$ day, respectively, in the reactors operated with mixtures containing 9,17 , and $27 \%$ (by mass) of contaminated sediment. Elliott and Elliott (2005) reported that high concentrations of substrate saturate the enzymes limiting the catalytic activity and, consequently, the biodegradation. Thus, based on the results obtained, it appears that, under the conditions, using mixtures containing 17 and $27 \%$ (by mass) of contaminated sediment, hydrocarbon concentrations toxic to the indigenous microbial cells were not reached.

Figure 6 shows the chromatogram for the organic extract of the sediment in the bioremediation tests conducted with the mixture containing $17 \%$ (by mass) of contaminated sediment. Similar chromatographic behavior was observed for the other experimental conditions tested. There was almost a complete absence of defined peaks, indicating close to total biodegradation of the aliphatic hydrocarbons within the range monitored $\left(n-C_{10}\right.$ to $\left.n-C_{36}\right)$.

The chromatographic profile indicates the persistence of the hydrocarbons in the range of lubricating oils (TPH-ORO), that is, those with a higher molecular mass, corroborating the findings of Alexander (1999), who reported that the biodegradation of these compounds is disadvantaged if compared with compounds of low and medium molecular mass, given the criterion of solubility in water, which determines the bioavailability and, consequently, the biodegradation.

From an analysis of the data listed in Table 1, it can be observed that total heterotrophyc bacteria (THB) showed a maximum concentration (approximately $10^{10}$ cells/g of sediment) at around 30 to 45 days of the process, regardless of the 
Table 1. Total heterotrophyc bacteria concentration (CFU/g) in the tests with mixtures of contaminated with uncontaminated sediment ( $9 \%, 17 \%$, and $27 \%$; by mass).

\begin{tabular}{lccc}
\hline Day & $9 \%$ & $17 \%$ & $27 \%$ \\
\hline 0 & $1.5 \pm 0.5 \times 10^{9}$ & $4.5 \pm 1.5 \times 10^{8}$ & $4.5 \pm 1.5 \times 10^{8}$ \\
15 & $4.5 \pm 1.0 \times 10^{8}$ & $4.6 \pm 1.1 \times 10^{9}$ & $2.5 \pm 1.5 \times 10^{9}$ \\
30 & $1.4 \pm 0.8 \times 10^{10}$ & $1.5 \pm 0.8 \times 10^{10}$ & $2.0 \pm 1.5 \times 10^{9}$ \\
45 & $1.4 \pm 1.0 \times 10^{10}$ & $1.1 \pm 0.7 \times 10^{10}$ & $1.4 \pm 1.0 \times 10^{10}$ \\
60 & $1.1 \pm 0.7 \times 10^{10}$ & $1.5 \pm 0.7 \times 10^{9}$ & $1.6 \pm 1.0 \times 10^{10}$ \\
90 & $1.1 \pm 0.5 \times 10^{10}$ & $7.5 \pm 1.8 \times 10^{8}$ & $1.4 \pm 1.0 \times 10^{10}$ \\
\hline
\end{tabular}

Table 2. Total fungi (CFU/g) in the tests with mixtures of contaminated with uncontaminated sediment $(9 \%, 17 \%$, and $27 \%$; by mass).

\begin{tabular}{lccc}
\hline Day & $9 \%$ & $17 \%$ & $27 \%$ \\
\hline 0 & $1.2 \pm 0.8 \times 10^{8}$ & $1.0 \pm 0.4 \times 10^{7}$ & $3.0 \pm 0.5 \times 10^{2}$ \\
15 & $1.6 \pm 1.0 \times 10^{8}$ & $3.0 \pm 1.4 \times 10^{6}$ & $9.0 \pm 2.2 \times 10^{5}$ \\
30 & $2.9 \pm 1.7 \times 10^{12}$ & $2.9 \pm 1.1 \times 10^{12}$ & $2.8 \pm 1.5 \times 10^{12}$ \\
45 & $2.9 \pm 2.0 \times 10^{12}$ & $2.5 \pm 1.7 \times 10^{12}$ & $2.6 \pm 1.7 \times 10^{12}$ \\
60 & $3.0 \pm 2.4 \times 10^{12}$ & $3.0 \pm 2.1 \times 10^{12}$ & $3.1 \pm 1.7 \times 10^{12}$ \\
90 & $1.0 \pm 0.5 \times 10^{12}$ & $2.0 \pm 1.0 \times 10^{12}$ & $2.0 \pm 1.4 \times 10^{12}$ \\
\hline
\end{tabular}

initial hydrocarbon concentration. During the 90 days of monitoring, it was verified that, in the case of the test conducted with the mixture containing $17 \%$ of contaminated sediment, there was a reduction in the THB after 45 days of the process. This behavior may be related to the deviations in the measurements or a reduction in the availability of the carbon source in these reactors, considering the maximum biodegradation results reported above. The results for the bacterial concentration were interpreted as providing evidence of the continuity of the bacterial activity and availability of nutrients. Considering the high percentage of biodegradation, the adaptation of the microbiota to the contaminant was also inferred (Suja et al., 2014).

The TF concentration (Table 2) reached a maximum after 30 days of the process, no alterations were observed after this period, and the concentration remained in the order of $10^{12}$ CFU/g. The capacity of the fungi, particularly the filamentous fungi, to biodegrade recalcitrant organic compounds has been widely reported in the literature, and some genera have been used in processes applied to the biological treatment of liquid effluents and solid residues (Colla et al., 2008). Considering this potential, the results obtained for the biodegradation may be related to the metabolically active fungal populations, corroborating the findings of Atagana (2004).

It is important to note that, for the sediments of the reactors which operated with mixtures of containing 9, 17 and $27 \%$ (by mass) of contaminated sediment, the PAH contents were below the limit of detection $(0.5 \mathrm{mg} / \mathrm{kg})$. The anthracene and phenathrene removal rates, over 90 days, were 1.1 and $0.2 \mathrm{mg} / \mathrm{kg}$ day, respectively (considering a linear model). These values are consistent with results reported in the literature (Atagana, 2004), and indicate excellent performance for the bioremediation strategies proposed for the contaminated sediment studied. 


\section{CONCLUSIONS}

The bioremediation, employing the biostimulation technique with NPK fertilizer, was efficient for the removal of total petroleum hydrocarbons from the Angolan fluvial sediment studied. The research carried out with mixtures of contaminated and uncontaminated sediment, to simulate landfarming conditions, verify that the reduction in the quantity of residual TPHs in the sediments was proportional to the quantity of TPHs present at the start of the tests. After 90 days of treatment, the concentrations of the $15 \mathrm{PAHs}$ monitored were reduced to non-detectable levels, indicating the potential of this technique. Thus, bioremediation was found to be an efficient and low cost alternative for the treatment of the sediment studied.

\section{ACKNOWLEDGEMENTS}

The authors of this work would like to thank CAPES and CNPq for the financial support.

\section{REFERENCES}

Alexander, M. Biodegradation and bioremediation. San Diego: Academic Press. 1999.

Atagana, H. I. Bioremediation of creosotecontaminated soil in South Africa by landfarming. Journal of Applied Microbiology, v.96 (3), p.510520, 2004.

http://dx.doi.org/10.1111/j.1365-2672.2003.02168.x

Castro, I. B.; Meirelles, C. A; Matthews-Cascon, H.; Fernandez, M. A. Thais (Stramonita) rustica (Lamarck, 1822) (Mollusca: Gastropoda: Thaididae), a potential bioindicator of contamination by organotin Northeast Brazil. Brazilian Journal of Oceanography, v.52 (2), p.135-139, 2004. http://dx.doi.org/10.1590/S1679-87592004000200005

Colla, L. M; Primaz, A. L.; Lima, M.; Bertolin, T. E.; Costa, J. A. V. Isolation and screening of fungi to bioremediation from triazine herbicide contaminated soil. Ciências Agrotecnicas, 32(3), p.809-813, 2008. http://dx.doi.org/10.1590/S1413$\underline{70542008000300016}$
Colombo, J. C.; Pelletier, E.; Brochu, C.; Khalil, M.; Catoggio, J.A Determination of hydrocarbons sources using $\mathrm{n}$-alcanes and polyaromatic hydrocarbons distribution indexes. Case study: Río de La Plata Estuary, Argentina. Environmental Science and Technology, v.23 (7), p.888-894, 1989. http://dx.doi.org/10.1021/es00065a019

Das, N.; Chandran P. Microbial degradation of petroleum hydrocarbon contaminants: an overview. Biotechnology Research International, v. 2011, p.1-13, 2011.

EPA - United States Environmental Protection Agency, Test Methods for Evaluating Solid Waste, SW-846, USEPA Office of Solid Waste and Emergency Response, Washington DC, 1996.

EIA - Energy Information Administration 2011. Country Analysis Briefs.

<http://www.eia.gov/countries/cab.cfm?fips=AO > (accessed December 20, 2011).

Elliott, W. H.; Elliott, D. C. Biochemistry and Molecular Biology. New York: Oxford University Press, 2005.

Figueiredo, J. Oil spill preclude water supply in Nzombo River (in portuguese). Jornal de Angola. October 24, 2009.

$<$ http://jornaldeangola.sapo.ao/18/0/derrame de petroleo priva populacao do consumo de agua do rio nzombo>, 2009. (accessed December 20, 2011).

Figueiredo, J. Beaches of Soyo polluted with crude oil (in portuguese). Jornal de Angola. http://iornaldeangola.sapo.ao/18/0/praias do soy o sujas com crude, 2009. (accessed December 20, 2011).

Franco, I.; Contin, M.; Bragato, G.; de Noboli, M. Microbial resilience of soils contaminated with crude oil. Geoderma, v.121, p.17-30, 2004. http://dx.doi.org/10.1016/i.geoderma.2003.10.002

Lladóa, S.,; Covinob, S.; Solanasa, A.M.; Viñasc, M.; Petrucciolid, M.; D'annibaled, A. Comparative assessment of bioremediation approaches to highly recalcitrant $\mathrm{PAH}$ degradation in a real industrial polluted soil. Journal of Hazardous Materials, v.248-249, p. 407-14, 2014. http://dx.doi.org/10.1016/i.jhazmat.2013.01.020 
Mao, J.; Luoa, Y.; Tenga, Y.; Lia, Z. Bioremediation of polycyclic aromatic hydrocarbon-contaminated soil by a bacterial consortium and associated microbial community changes. International Biodeterioration and Biodegradation, v.70, p.141-47, 2012.

http://dx.doi.org/10.1016/j.ibiod.2012.03.002

Marin, J. A.; Hernandez, T.; García, C. Bioremediation of oil refinery sludge by landfarming in semiarid conditions: influence on soil microbial activity. Environmental Research, v.98 (2), p.185-95, 2005.

http://dx.doi.org/10.1016/i.envres.2004.06.005

Oliveira, F. J. S.; de França F.P. Increase in removal of polycyclic aromatic hydrocarbons during bioremediation of crude oil-contamined sandy soil. Applied Biochemistry and Biotechnology, v. 121-124, p. 593-603, 2005. http://dx.doi.org/10.1385/ABAB:122:1-3:0593

Pereira Netto, A. D.; Moreira, J. C.; Dias, A. E. X. O.; Arbilla, G.; Ferreira, L. F. V.; Oliveira, A. S.; Barek. J. Evaluation of human contamination with polycyclic aromatic hydrocarbons (PAHs) and their nitrated derivatives (NHPAs): a review of methodology (in Portuguese). Química Nova, 23(6), p.765-773, 2000.

http://dx.doi.org/10.1590/\$0100-40422000000600010

Röling, W. F. M.; van Versevld, H. W. Natural attenuation: What does the subsurface have in store? Biodegradation, v.13, p.53-64, 2002. http://dx.doi.org/10.1023/A:1016310519957

Salam, L. B.; Obayori, O. S. Fluorene biodegradation potential of Bacillus strains isolated from tropical soil hydrocarbons-contaminated soils. African Journal of Microbiology, v.13, p.1554-59, 2014.
Suja, F.; Rahim, F.; Taha, M. R.; Hambali, N.; Rizal Razali, M.; Khalid, A.; Hamzah, A. Effects of local microbial bioaugmentation and biostimulation on the bioremediation of total petroleum hydrocarbons (TPH) in crude oil contaminated soil based on laboratory and field observations. International Biodeterioration and Biodegradation, v.90, p.115-122, 2014.

http://dx.doi.org/10.1016/i.ibiod.2014.03.006

Trindade, P. V. O.; Sobral, L.G.; Rizzo, A. C. L.; Leite, S. G. F.; Soriano A. U. Bioremediation of a weathered and a recently oil-contaminated soils from Brazil: a comparison study. Chemosphere, v.58 (4), p.515-22, 2005.

http://dx.doi.org/10.1016/i.chemosphere.2004.09.021

Vasconcelos, U.; Oliveira, F. J. S.; de França, F. P. Removal of High-molecular weight polycyclic aromatic hydrocarbons. Química Nova, v.34 (2): p. 218-221.

http://dx.doi.org/10.1590/S0100-40422011000200009

Watwood, M. E.; White, C. S.; Dahn C. N. Methodological modifications for accurate and efficient determination of contaminant biodegradation in unsaturated calcareous soil. Applied Environmental Microbiology, v.57 (3), p.717-720, 1991. 